\title{
STAKEHOLDER PARTICIPATION AND PROJECT SUSTAINABILITY A CASE OF DEAF DONOR FUNDED PROJECT IN KICUKIRO, RWANDA
}

\author{
Alexia UWAMARIYA ${ }^{1 *}$, Dr Ernest SAFARI ${ }^{2}$, Dr. Osiemo A. Kengere ${ }^{3}$ \\ ${ }^{*}$ School of Business and Economic, Mount Kenya University, Kigali, Rwanda \\ ${ }^{2,3}$ Master of Business Administration (Project Management Option), Mount Kenya University, Kigali, Rwanda
}

*Corresponding Author: -

\begin{abstract}
: -
Researches has shown that due to less participation of stakeholders in project sustainability, most of donor funded projects fail or get stuck just after withdrawal of funds by donors. Hence, the purpose of this study of assessing the contribution of stakeholder's participation in promoting project sustainability with a case study of Deaf Donor Funded Project in Kicukiro. The researcher used descriptive research design to a target population of 246 people in which 152 respondents were chosen using the formula of Yamane (1967) with census and purposive sampling techniques. The questionnaires were distributed to the respondents because the researcher did self administration of questionnaires while collecting data,
\end{abstract}

Keywords: Stakeholder participation, Project Sustainability, Deaf Donor Funded Project, Rwanda. 


\section{INTRODUCTION}

but a sign language translator was hired to help capture all the necessary information. The analysis of the questionnaire was done through use of SPSS version 21.0 hence the use of descriptive, regression and correlation tables within this study about participation of stakeholders and project sustainability. The findings also prove that there is a relationship between Skills and Ownership $(\mathrm{p}=.851$ and sig=.000), between skills and continuation $(\mathrm{p}=.786$ and sig=.000), between material and effective leader $(\mathrm{p}=.899$ and sig=.000) because all calculated $\mathrm{p}$ values are less than 0.01 level of significance.

Most donor funded projects fail or get stuck just after withdrawal of funds by donors due to potential barriers such as limited skills to run project due to illiteracy, limited resources and materials of stakeholders. Hence, the implication of stakeholder participation concept that was in existence for almost 50 years, though direct and indirect beneficiaries of the donor funded projects kept seeing themselves as benefiting part of the project rather than being part and parcel of the project implementation and sustainability (Peter et al., 2015). Donors and partners find difficulties when it goes to the ownership and participation of stakeholders in the project because of no capabilities, skills and competences due to illiteracy in the project.

In spite of the fact that the study conducted by Cohen and Uphoff (2010) have argued that project sustainability should take into account the economic, cultural and financial environment, as well as the participation of the pastime performance that contributes a necessary role in the promotion of sustainability of the project and its ownership in case donors withdraw their funds.

Research has shown that well designed stakeholders participation process leads to project success and hence its sustainability (Bal, et al., 2013 and Ndengwa, 2015). Although there are studies conducted on stakeholders' participation in promoting project sustainability in Rwanda, it is still not very clear whether the direct beneficiaries like deaf people and their families are considered as project stakeholders who can contribute for project sustainability. It is also important to assess the effect of resource contribution on project sustainability of donor-funded project in Kicukiro, the role of material contribution on project sustainability of donor funded project in Kicukiro and the relationship between skills contribution on project sustainability of donor funded project in Kicukiro. It is in this context the researcher wants to conduct a study on assessing stakeholder's participation in promoting project sustainability with a case study of Deaf Donor Funded Project in Kicukiro.

\section{Research Objectives \\ 2.1 General objective}

To assess the contribution of stakeholders' participation in promoting project sustainability with a case study of Deaf Donor Funded Project in Kicukiro District.

\subsection{Specific Objectives}

(i) To assess the effect of resource contribution on project sustainability of donor funded project in Kicukiro

(ii) To evaluate the role of material contribution on project sustainability of donor funded project in Kicukiro

(iii) To establish the relationship between skills contribution and project sustainability of donor funded project in Kicukiro

\section{Literature Review}

Peter et al., (2013), referred to that project to be sustainable, as a multidimensional attribute of sustainability such as the social, cultural, financial and environmental pillar by the design of the project and the system must be taken into account of the record and community involvement have to be fundamental part of the stakeholders who want to keep the sustainability of their project. The study argued that, it is imperative that community collaborators perceive their personal needs and develop community action plans, emphasizing the use of the community's inherent knowledge, capacity, and available sources to enable them to domesticate a modern approach for tackling their very own problems and elevating self-sufficiency in source phrases when donor financial sources are withdrawn. Because, the findings revealed that there is an significant relationship between the identification of personal need and the sustainability of the project with 0.781 Pearson correlation and the calculated sig. of 0.000 at 0.01 degrees of significance.

Stakeholder participation involves participation as a contribution to the implementation of a project with control over assets and decision-making. In a contribution of beneficial resources, external distributors have assumed their role of instructing participants the options for their problems, and then the interest contributes in terms of sources to preserve project operations (Pretty, 2015). The activity of external carriers is only to legitimize their existence in the project barring any intention of containing men and women in the allocation of useful resource Meanwhile, members hope their position is to contribute to the provision of local resources to clear up matters and be receptive and attentive to advocates 'directions to enhance resource contribution for the project sustainability (Pretty, 2015).

Stakeholder participation in the project entails a contribution of material and net practicable through both direct and indirect beneficiaries and play an indispensable function in enhancing project sustainability. Other research stated that stakeholder participation in initiatives contributes to increased resources, such as the financial, staffing and manpower supply that make the project effective and positive in its operation (Mukunga, 2012; and Ndegwa, 2015). 
Collaborative Partnerships enhances material contribution by the stakeholders including governments and agencies to enlarge the scarce resource for the sake of project sustainability (Mukunga (2012). However, skills contribution lead to power gap among the involved stakeholders, difficulties in reaching consensus at appropriate time as different classes of stakeholders are at stake lead to the capacity building of the involved stakeholders, number of theories that can raise difficulties during decision making process or reaching a consensus because there is a single actor working at stake depending on the material contribution and the economic capabilities of stakeholders.

The study by Chizimba (2013) cited that the project is sustainable if it only has a build exit approach and, moreover, if sustainability is to be accomplished, the intervention involves the local and builds the capacities of local authorities to obtain big benefits to undertake or to obtain this, working in collaboration is not a vital option in any intervention. The study recommends that the community prefer to have an absolute expertise of the project's exit strategies. The study positioned more emphasis on community involvement, however the important purpose of the data, whilst the project is sustainable, the community need to be concerned at all stages of the project cycle that include the design of the exit strategy to preserve and enhance the impact of the intervention.

Mukunga (2012) performed research on the significance of community participation in the ongoing construction of Tanzania's school, the findings showed that for a project or intervention to be sustainable, collaborative participation and the contribution of capacity have an integral function at a rate of $67.8 \%$ as it was regarded as active. The study found that, participation through material donation was a primary issue of community ownership at $32.1 \%$, therefore, the sustainability of the intervention. The study also emphasized the significance and usefulness of knowledge on how to know if solely people in the community have been moreover educated to take charge of the project even in minor activities. The research recommended on the significance of the contribution of skills and capabilities, as it motives people to make the joint decisions and choice to the number of matters associated to their social and economic development.

\section{Materials and Methods}

Correlational research design was applied to facilitate the researcher to establish the relationship between skills contribution and project sustainability of donor funded project in Kicukiro through inclusion of interview and narratives as qualitative and quantitative data for more comprehensive analysis in order to accumulate depth and insights to numbers and perceptions (Banerjee \& Chaudhury, 2010).

This study was carried out in Kicukiro District at Deaf Donor Funded Project Office, since the study is about stakeholders' participation in promoting project sustainability. The study considered the whole population of 246 people including 8 donors, 9 employees and 229registered direct beneficiaries who are involved in tailoring activities, braiding and other activities funded by the project. The sample size of the study was drawn from the target population of 246 of Deaf Donor Funded Project using formula of Yamane (1967) model that was adopted form (Banerjee \& Chaudhury, 2010).

$$
\begin{gathered}
n=\frac{N}{1+N e^{2}} \\
n=\frac{246}{1+246(0.05)^{2}} \\
n=152
\end{gathered}
$$

Whereby "N" stands for target population of 246 people within Deaf Donor Funded Project, " $n$ " stands for the sample size who was the respondents within this study, and "e" stands for margin of error $(\mathrm{MoE}=0.05)$

The sampling technique was census and purposive sampling method because the population to be used was not homogenous so, a need for using census and purposive sampling methods was required. For the case of census, 8 donors and 9 project employees were employed as respondents in the study while for the case of purposive sampling technique only 135 beneficiaries who know how to read and write were random selected as respondents of the study.

This part entails data analysis procedure and tools used such as multiple linear regression and correlation analysis through the help of SPSS to have an entire research report where the response rate of the respondents were 152 $(100 \%)$ because the researcher has self-administered the questionnaire to ensure no questionnaire has not returned. It covered writing and editing, tabulation and interpretation of data. The data accrued have been coded, cleaned and analyzed with the SPSS 21.0 model.

The researcher has used regression analysis with the regression equation; $Y=\beta 0+\beta 1 \times 1+\beta 2 \times 2+\beta 3 \times 3$, Y represents the stakeholder participation, X1 represents project ownership, X2 represents continuation of the project, X3 represents effective leadership. The Pearson correlation analysis was applied in this study to determine the relationship between stakeholder participation and project sustainability. 


\section{Results}

5.1 The effect of resource contribution on project sustainability of donor funded project in Kicukiro District

Table 5.1: Local resources contribution considered

\begin{tabular}{|c|c|c|c|c|c|c|c|}
\hline Local resources contribution & 5 & 4 & 3 & 2 & 1 & Mean & Std. \\
\hline $\begin{array}{l}\text { During project } \begin{array}{r}\text { design } \\
\text { stakeholder } \\
\text { resources are considered }\end{array} \\
\text { ecomic }\end{array}$ & $1(0.7 \%)$ & $12(7.9 \%)$ & $22(14.5 \%)$ & $52(34.2 \%)$ & $65(42.8 \%)$ & 1.894 & .970 \\
\hline $\begin{array}{l}\text { During project design } \\
\text { stakeholders are involved }\end{array}$ & $0(0.0 \%)$ & $3(2.0 \%)$ & $4(2.6 \%)$ & $17(11.2 \%)$ & $128(84.2 \%)$ & 1.223 & .589 \\
\hline $\begin{array}{l}\text { During project identification } \\
\text { stakeholders social } \\
\text { knowledge is considered }\end{array}$ & $0(0.0 \%)$ & $2(1.3 \%)$ & $3(2.0 \%)$ & $19(12.5 \%)$ & $128(84.2 \%)$ & 1.203 & .531 \\
\hline $\begin{array}{l}\text { During project design the } \\
\text { culture of stakeholders is } \\
\text { recognized }\end{array}$ & $0(0.0 \%)$ & $3(2.0 \%)$ & $4(2.6 \%)$ & $15(9.9 \%)$ & $130(85.5 \%)$ & 1.210 & .582 \\
\hline $\begin{array}{l}\text { The environment of } \\
\text { stakeholders is recognized } \\
\text { during project identification }\end{array}$ & $0(0.0 \%)$ & $2(1.3 \%)$ & $3(2.0 \%)$ & $18(11.8 \%)$ & $129(84.9 \%)$ & 1.197 & .527 \\
\hline $\begin{array}{l}\text { Stakeholders identify their } \\
\text { needs during project design }\end{array}$ & $0(0.0 \%)$ & $2(1.3 \%)$ & $2(1.3 \%)$ & $62(40.8 \%)$ & $86(56.6 \%)$ & 1.473 & .597 \\
\hline $\begin{array}{l}\text { Stakeholder participate in } \\
\text { drawing action plans }\end{array}$ & $2(1.3 \%)$ & $2(1.3 \%)$ & $4(2.6 \%)$ & $13(8.6 \%)$ & $131(86.2 \%)$ & 1.230 & .685 \\
\hline $\begin{array}{l}\text { Community inherent } \\
\text { knowledge is used in project } \\
\text { design }\end{array}$ & $17(11.2 \%)$ & $12(7.9 \%)$ & $17(11.2 \%)$ & $25(16.4 \%)$ & $81(53.3 \%)$ & 2.072 & 1.405 \\
\hline $\begin{array}{l}\text { Capacity of the stakeholder is } \\
\text { sustained during project } \\
\text { implementation }\end{array}$ & $6(3.9 \%)$ & $7(4.6 \%)$ & $2(1.3 \%)$ & $11(7.2 \%)$ & $126(82.9 \%)$ & 1.394 & 1.010 \\
\hline $\begin{array}{l}\text { Available local resource all } \\
\text { use during } \\
\text { implementation to increase } \\
\text { ownership }\end{array}$ & $0(0.0 \%)$ & $2(1.3 \%)$ & $3(2.0 \%)$ & $22(14.5 \%)$ & $125(82.2 \%)$ & 1.223 & .5422 \\
\hline $\begin{array}{l}\text { Innovative approach is used } \\
\text { to raise the capacity of local } \\
\text { community }\end{array}$ & $0(0.0 \%)$ & $16(10.5 \%)$ & $9(5.9 \%)$ & $22(14.5 \%)$ & $105(69.1 \%)$ & 1.684 & 1.268 \\
\hline $\begin{array}{l}\text { Capacity building is } \\
\text { considered to increase self- } \\
\text { reliance of the stakeholders }\end{array}$ & $2(1.3 \%)$ & $1(.7 \%)$ & $4(2.6 \%)$ & $11(7.2 \%)$ & $134(88.2 \%)$ & 1.197 & .641 \\
\hline $\begin{array}{l}\text { stakeholders participate in } \\
\text { control of resources during } \\
\text { project monitoring }\end{array}$ & $37(24.3 \%)$ & $10(6.6 \%)$ & $16(10.5 \%)$ & $35(23.0 \%)$ & $54(35.5 \%)$ & 2.611 & 1.599 \\
\hline $\begin{array}{l}\text { Stakeholders participate in } \\
\text { decision making }\end{array}$ & $15(9.9 \%)$ & $16(10.5 \%)$ & $11(7.2 \%)$ & $6(4.0 \%)$ & $104(68.4 \%)$ & 1.894 & 1.438 \\
\hline $\begin{array}{l}\text { Stakeholder participate in } \\
\text { provision of local resources } \\
\text { to solve the problems }\end{array}$ & $8(5.3 \%)$ & $13(8.6 \%)$ & $28(18.4 \%)$ & $42(27.6 \%)$ & $61(40.1 \%)$ & 2.111 & 1.182 \\
\hline Total Mean & & & & & & 1.574 & \\
\hline
\end{tabular}

Source: Primary Data (2020)

The results in 5.1 demonstrate the total mean is 1.574 that shows strong tendency implying that local resources considered affect project sustainability. Thus, the results of the study are supported by the findings of the study of Pretty (2015) who asserted that members of the project contribute to the provision of local resources to clear up matters and be receptive and attentive to advocates directions to enhance resource contribution for the project sustainability.

Table 5.2: Donors influence local resources contribution considered

\begin{tabular}{llllllll}
\hline & 5 & 4 & 3 & 2 & 1 & Mean & Std. \\
\hline $\begin{array}{l}\text { Donors influence local resources } \\
\text { contribution consideration }\end{array}$ & $0(0.0 \%)$ & $1(.7 \%)$ & $1(.7 \%)$ & $8(5.3 \%)$ & $142(93.3 \%)$ & 1.085 & .362 \\
$\begin{array}{l}\text { Donors allow the stakeholders to } \\
\text { have control over their project }\end{array}$ & $0(0.0 \%)$ & $1(.7 \%)$ & $2(1.3 \%)$ & $5(3.3 \%)$ & $144(94.7 \%)$ & 1.078 & .373 \\
$\begin{array}{l}\text { Donors emphasize participation } \\
\text { of stakeholders in decision } \\
\text { making process }\end{array}$ & $7(4.6 \%)$ & $11(7.2 \%)$ & $19(12.5 \%)$ & $16(10.5 \%)$ & $99(65.1 \%)$ & 1.756 & 1.196 \\
$\begin{array}{l}\text { Donors assume the role as } \\
\text { teaching and sponsoring the local } \\
\text { project }\end{array}$ & & & & & & \\
$\begin{array}{l}\text { Donors oversees only resource } \\
\text { allocation }\end{array}$ & $0(0.0 \%)$ & $2(1.3 \%)$ & $2(1.3 \%)$ & $4(2.6 \%)$ & $144(94.7 \%)$ & 1.092 & .436 \\
$\begin{array}{l}\text { Donors allows the stakeholders to } \\
\text { bring resources to increase } \\
\text { ownership }\end{array}$ & $5(3.3 \%)$ & $11(7.2 \%)$ & $11(7.2 \%)$ & $24(15.8 \%)$ & $101(66.4 \%)$ & 1.651 & 1.099 \\
$\begin{array}{l}\text { Donors emphasize use of local } \\
\text { knowledge to solve the problem }\end{array}$ & $0(0.0 \%)$ & $1(.7 \%)$ & $1(.7 \%)$ & $8(5.3 \%)$ & $142(93.4 \%)$ & 1.085 & .362 \\
\begin{tabular}{l} 
Total Mean \\
\hline
\end{tabular}
\end{tabular}

Source: Primary Data (2020) 
The results in Table 4.5 has shown that total mean is 1.266 that tends to a very great extent implying that donors influence local resources contribution considered to promote project sustainability of donor funded project in Kicukiro District.

Table 5.3: Model summary of stakeholder participation and ownership as an indicator of sustainability of deaf donor funded project

\begin{tabular}{cccc}
\hline Model R & R Square & Adjusted R Square & Std. Error of the Estimate \\
\hline 020a & .863 & .860 & .20615 \\
\hline
\end{tabular}

a. Predictors: (Constant), Material, Skills, Resources

Source: Primary Data (2020)

The results in Table 5.3 show that the coefficient $\mathrm{R} 0.929$ suggests that the participation of stakeholders has a relationship with the ownership of deaf donor funded project. The coefficient of determination $0.863 \mathrm{R}$ Square shows that the participation of activity businesses explains $86.3 \%$ of growth variability in the ownership of deaf donor funded project. Thus, implies that predictors of participation of stakeholders such as material, skills and resources that affect progress $86.3 \%$ of ownership of deaf donor funded project.

Table 5.4: Analysis of Variance (ANOVA) of stakeholder participation and ownership of deaf donor funded project

\begin{tabular}{llllll}
\hline Model & Sum of Squares & df & Mean Square & F & Sig. \\
\hline Regression & 39.546 & 3 & 13.182 & 310.194 & $.000^{\mathrm{b}}$ \\
Residual & 6.289 & 148 & .042 & & \\
Total & 45.836 & 151 & & & \\
\hline
\end{tabular}

a. Dependent Variable: Ownership

b. Predictors: (Constant), Material, Skills, Resources

Source: Primary Data, 2020

The Table 5.4 demonstrates that there is a significant relationship between stakeholder participation and ownership because the calculated sig. value of 0.00 is less than 0.05 significance level. Therefore, the statistical model that predicts the correlation between stakeholder participation and ownership of deaf donor funded project is significant.

Table 5.5: Coefficients of stakeholder participation and ownership as indicator of sustainability of deaf donor funded project

\begin{tabular}{|c|c|c|c|c|c|}
\hline \multirow[t]{2}{*}{ Model } & \multicolumn{2}{|c|}{ Unstandardized Coefficients } & \multirow{2}{*}{$\begin{array}{l}\text { Standardized Coefficients } \\
\text { Beta }\end{array}$} & \multirow[t]{2}{*}{$\mathrm{t}$} & \multirow[t]{2}{*}{ Sig. } \\
\hline & B & Std. Error & & & \\
\hline (Constant) & -.034 & .046 & & -.735 & .464 \\
\hline Skills & .344 & .061 & .319 & 5.597 & .000 \\
\hline Resources & .003 & .085 & .003 & .036 & .002 \\
\hline Material & .668 & .112 & .646 & 5.938 & .000 \\
\hline
\end{tabular}

Dependent Variable: Ownership

Source: Primary Data, 2020

The Table 5.5 point out that stakeholder participation predictors have positive coefficients that has impact on progress of ownership deaf donors funded in Kicukiro District. The analysis indicates that there is a significant relationship between stakeholder participation and ownership due to the fact all calculated $\mathrm{p}$ values are lesser than0.05 sig. level. Hence, the coefficients give regression model, $Y=\beta 0+\beta 1 X 1+\beta 2 X 2+\beta 3 X 3+\beta$. Therefore, it becomes $\mathrm{Y}=-.034+.344 \mathrm{X} 1+.003 \mathrm{X} 2+.668 \mathrm{X} 3$, this regression equations shows that there is a positive significant between participation of stakeholders and ownership of deaf donor funded project in Kicukiro District.

The first objective established to indicate the relationship between skills and ownership proves that there is a positive and significant relationship $(b=.344$ and $p=.000)$ which is lesser than 0.05 level of significance; the second objective established to indicate the relationship between resources and ownership has a positive and significant relationship ( $\mathrm{b}=-.003$ and $\mathrm{p}=.002)$ which is lesser than 0.05 level of significance; the third objective established to indicate the relationship between materials and ownership has a positive and significant relationship $(b=.668$ and $p=.000)$ which is lesser than 0.05 level of significance. Thus, implies that there is a positive significant relationship between participation of stakeholders and ownership of deaf donor funded project in Kicukiro District. 


\subsection{The role of material contribution on sustainability of deaf donor funded project in Kicukiro} District

Table 5.6: Material contribution and sustainability of deaf donor funded project

\begin{tabular}{|c|c|c|c|c|c|c|c|}
\hline Statement & 1 & 2 & 3 & 4 & 5 & Mean & Std. \\
\hline $\begin{array}{l}\text { To make the project very } \\
\text { efficient and effective } \\
\text { stakeholders should raise } \\
\text { finances }\end{array}$ & $3(2.0 \%)$ & $10(6.6 \%)$ & $11(7.2 \%)$ & $13(8.6 \%)$ & $115(75.7 \%)$ & 1.506 & 1.016 \\
\hline $\begin{array}{l}\text { Stakeholders should work as } \\
\text { project personnel to raise } \\
\text { material contribution }\end{array}$ & $10(6.6 \%)$ & $14(9.2 \%)$ & $2(1.3 \%)$ & $12(7.9 \%)$ & $114(75.0 \%)$ & 1.644 & 1.268 \\
\hline $\begin{array}{l}\text { Stakeholders receive } \\
\text { monthly and quarterly } \\
\text { material report }\end{array}$ & $0(0.0 \%)$ & $12(7.9 \%)$ & $15(9.9 \%)$ & $23(15.1 \%)$ & $102(67.1 \%)$ & 1.585 & .959 \\
\hline $\begin{array}{l}\text { Stakeholders receive } \\
\text { monthly and quarterly } \\
\text { financial report }\end{array}$ & $2(1.3 \%)$ & $22(14.5 \%)$ & $29(19.1 \%)$ & $19(12.5 \%)$ & $80(52.6 \%)$ & 1.993 & 1.193 \\
\hline $\begin{array}{l}\text { Stakeholders contribute } \\
\text { material inputs for project } \\
\text { sustainability }\end{array}$ & $2(1.3 \%)$ & $7(4.6 \%)$ & $26(17.1 \%)$ & $23(15.1 \%)$ & $94(61.8 \%)$ & 1.684 & .999 \\
\hline $\begin{array}{l}\text { Stakeholders take } \\
\begin{array}{l}\text { decision } \\
\text { regarding }\end{array} \\
\text { contribution }\end{array}$ & $0(0.0 \%)$ & $4(2.6 \%)$ & $8(5.3 \%)$ & $28(18.4 \%)$ & $112(73.7 \%)$ & 1.368 & .706 \\
\hline $\begin{array}{l}\text { Stakeholders carry out } \\
\text { material project planning for } \\
\text { sustainability of the project }\end{array}$ & $0(0.0 \%)$ & $1(.7 \%)$ & $1(.7 \%)$ & $23(15.1 \%)$ & $129(84.9 \%)$ & 1.151 & .359 \\
\hline $\begin{array}{l}\text { Stakeholders monitors the } \\
\text { material use during project } \\
\text { monitoring process }\end{array}$ & $0(0.0 \%)$ & $8(5.3 \%)$ & $2(1.3 \%)$ & $4(2.6 \%)$ & $138(90.8 \%)$ & 1.210 & .715 \\
\hline $\begin{array}{l}\text { Stakeholders provide labor } \\
\text { power }\end{array}$ & $0(0.0 \%)$ & $6(3.9 \%)$ & $6(3.9 \%)$ & $16(10.5 \%)$ & $124(81.6 \%)$ & 1.302 & .728 \\
\hline $\begin{array}{l}\text { Stakeholders identify } \\
\text { material need of the project }\end{array}$ & $0(0.0 \%)$ & & $9(5.9 \%)$ & $25(16.4 \%)$ & $118(77.6 \%)$ & 1.282 & .568 \\
\hline $\begin{array}{l}\text { Stakeholder should also pay } \\
\text { for services given by the } \\
\text { project to enhance } \\
\text { sustainability }\end{array}$ & $0(0.0 \%)$ & $2(1.3 \%)$ & $6(3.9 \%)$ & $19(12.5 \%)$ & $125(82.2 \%)$ & 1.243 & .586 \\
\hline $\begin{array}{l}\text { Stakeholder should organize } \\
\text { fundraising to ensure } \\
\text { sustainability of the project }\end{array}$ & $0(0.0 \%)$ & $0(0.0 \%)$ & $11(7.2 \%)$ & $19(12.5 \%)$ & $122(80.3 \%)$ & 1.269 & .586 \\
\hline $\begin{array}{l}\text { Stakeholders should } \\
\text { financially contribute to } \\
\text { project sustainability }\end{array}$ & $0(0.0 \%)$ & $3(2.0 \%)$ & $6(3.9 \%)$ & $18(11.8 \%)$ & $125(82.2 \%)$ & 1.256 & .625 \\
\hline Total Mean & & & & & & 1.423 & \\
\hline
\end{tabular}

Source: Primary Data (2020)

Table 5.6 indicates a total mean is 1.423 , which shows the strong tendency implying that material contribution plays significant role project sustainability which is supported by the study of Mukunga (2012) who asserted that collaborative partnership enhances material contribution by including stakeholders such governments and agencies to enlarge the scarce resource for the sake of project sustainability. Thus, this previous study supported the results of the current because it shows that still material contribution enlarges scarce resource to enhance project sustainability.

Table 5.7: Model summary of stakeholder participation and continuation as an indicator of sustainability of deaf donor funded project

a. Predictors: (Constant), Material, Skills, Resources

\begin{tabular}{lllll}
\hline Model & R & R Square & Adjusted R Square & Std. Error of the Estimate \\
\hline $.791^{\mathrm{a}}$ & .625 & .618 & .36958 \\
\hline
\end{tabular}

Source: Primary Data (2020)

The results in Table 5.7 shows that the $\mathrm{R} .791$ coefficient shows that stakeholder participation is associated to the continuation of the project. The coefficient of determination $.625 \mathrm{R}$ square also indicates that stakeholder participation accounts for $62.5 \%$ of the variability of progress in continuation of deaf donor funded project. Thus, implies that predictors of participation of stakeholders such as material, skills and resources that affect progress $62.5 \%$ of continuation of deaf donor funded project. 
Table 5.8: Analysis of Variance (ANOVA) of stakeholder participation and continuation as an indicator of sustainability of deaf donor funded project

\begin{tabular}{llllll}
\hline Model & Sum of Squares & df & Mean Square & F & Sig. \\
\hline Regression & 33.726 & 3 & 11.242 & 82.305 & $.000^{\mathrm{b}}$ \\
Residual & 20.215 & 148 & .137 & & \\
Total & 53.941 & 151 & & & \\
\hline
\end{tabular}

a. Dependent Variable: Continuation

b. Predictors: (Constant), Material, Skills, Resources

Source: Primary Data, 2020

The Table 5.8 show that there is a significant relationship between stakeholder participation and continuation, as the calculated significance level of 0.00 is less than 0.05 significance value. Therefore, the statistical model observes the correlation between stakeholder participation and continuation of deaf donor funded project is significant.

Table 5.9: Coefficients of stakeholder participation and continuation as an indicator of sustainability of deaf donor funded project

\begin{tabular}{|c|c|c|c|c|c|}
\hline Model & $\begin{array}{l}\text { Unstandardized } \\
\text { B }\end{array}$ & $\begin{array}{l}\text { Coefficients } \\
\text { Std. Error }\end{array}$ & $\begin{array}{l}\text { Standardized } \\
\text { Beta }\end{array}$ & Coefficients t & Sig. \\
\hline (Constant) & .154 & .083 & & 1.869 & .064 \\
\hline Skills & .821 & .110 & .702 & 7.444 & .000 \\
\hline Resources & .241 & .152 & .220 & 1.580 & .016 \\
\hline Material & .318 & .202 & .284 & 1.579 & .017 \\
\hline
\end{tabular}

a. Dependent Variable: Continuation

Source: Primary Data (2020)

The results in Table 5.9 show that stakeholder participation predictors have suitable coefficients that enhance the great effect on the progress of continuation of the deaf donor funded project in Kicukiro District. The analysis suggests that there is a significant relationship between stakeholder participation and continuation, as all calculated $\mathrm{p}$ values are less than 0.05 ranges of significance. Therefore, the coefficients of a regression model, $\mathrm{Y}=$ $\beta 0+\beta 1 \mathrm{X} 1+\beta 2 \mathrm{X} 2+\beta 3 \mathrm{X} 3$. Therefore, it will turn out to be $\mathrm{Y}=.154+.821 \mathrm{X} 1+.241 \mathrm{X} 2+.318 \mathrm{X} 3$, this regression equation suggests that there is a remarkable and significant between stakeholder participation and the continuation of the donor-funded project Kicukiro District.

The first objective established to indicate the relationship between skills and continuation proves that there is a positive and significant relationship $(b=.821$ and $\mathrm{p}=.000)$ which is lesser than 0.05 level of significance; the second objective established to indicate the relationship between resources and continuation has a positive and significant relationship $(b=.241$ and $p=.016)$ which is lesser than 0.05 level of significance; the third objective established to indicate the relationship between materials and continuation has a positive and significant relationship $(b=.318$ and $p=.017)$ which is lesser than 0.05 level of significance. Thus, implies that there is a positive significant relationship between participation of stakeholders and continuation of deaf donor funded project in Kicukiro District.

\subsection{The relationship between skills contribution and project sustainability of donor funded project in} Kicukiro District

Table 5.10: Extent skills contribution is related to project sustainability

\begin{tabular}{|c|c|c|c|c|c|c|c|}
\hline Statements & 5 & 4 & 3 & 2 & $12 \times$ & Mean & Std. \\
\hline $\begin{array}{l}\text { Stakeholders } \begin{array}{l}\text { share } \\
\text { skills } \\
\text { required } \\
\text { sustainability }\end{array} \text { project }\end{array}$ & $\mathrm{O}(.0 \%)$ & $0(0.0 \%)$ & $15(9.9 \%)$ & $19(12.5 \%)$ & $118(77.6 \%)$ & 1.322 & .646 \\
\hline $\begin{array}{l}\text { Managerial skills are } \\
\text { required for project } \\
\text { sustainability }\end{array}$ & $25(16.4 \%)$ & $13(8.6 \%)$ & $28(18.4 \%)$ & $50(32.9 \%)$ & $36(23.6 \%)$ & 2.611 & 1.371 \\
\hline $\begin{array}{l}\text { Communication skills are } \\
\text { required for } \\
\text { sustainability }\end{array}$ & $\mathrm{O}(.0 \%)$ & $0(0.0 \%)$ & $1(.7 \%)$ & $8(5.3 \%)$ & $143(94.0 \%)$ & 1.065 & .274 \\
\hline $\begin{array}{l}\text { Stakeholders' planning skills } \\
\text { are required for project } \\
\text { sustainability }\end{array}$ & $\mathrm{O}(.0 \%)$ & $\mathrm{O}(0.0 \%)$ & $1(.7 \%)$ & $5(3.3 \%)$ & $146(96.0 \%)$ & 1.046 & .239 \\
\hline $\begin{array}{l}\text { Stakeholders share theories } \\
\text { for project sustainability }\end{array}$ & $7(4.6 \%)$ & $11(7.2 \%)$ & $19(12.5 \%)$ & $16(10.5 \%)$ & $99(65.1 \%)$ & 1.756 & 1.196 \\
\hline $\begin{array}{l}\text { identify } \\
\text { togeholders } \\
\text { together the project needs }\end{array}$ & $\mathrm{O}(.0 \%)$ & $0(.0 \%)$ & $1(.7 \%)$ & $14(9.2 \%)$ & $137(90.1 \%)$ & 1.105 & .328 \\
\hline $\begin{array}{l}\text { Stakeholders give theories } \\
\text { inputs for project } \\
\text { sustainability }\end{array}$ & $\mathrm{O}(.0 \%)$ & $2(1.3 \%)$ & $2(1.3 \%)$ & $4(2.6 \%)$ & $144(94.7 \%)$ & 1.092 & .436 \\
\hline $\begin{array}{l}\text { Stakeholders gather meeting } \\
\text { and being told the project } \\
\text { situation }\end{array}$ & $4(2.6 \%)$ & $11(7.2 \%)$ & $11(7.2 \%)$ & $22(14.5 \%)$ & $104(68.4 \%)$ & 1.611 & 1.067 \\
\hline $\begin{array}{l}\text { Stakeholder interpersonal } \\
\text { skills are required for project } \\
\text { sustainability }\end{array}$ & $0(.0 \%)$ & $0(0.0 \%)$ & $1(.7 \%)$ & $9(5.9 \%)$ & $143(93.4 \%)$ & 1.059 & .236 \\
\hline $\begin{array}{l}\text { Stakeholders identify the } \\
\text { location of project together }\end{array}$ & $3(2.0 \%)$ & $10(6.6 \%)$ & $11(7.2 \%)$ & $14(9.2 \%)$ & $114(75.0 \%)$ & 1.513 & 1.016 \\
\hline $\begin{array}{l}\text { Stakeholders shares kills in } \\
\text { the project to ensure project } \\
\text { sustainability }\end{array}$ & $12(7.9 \%)$ & $14(9.2 \%)$ & $2(1.3 \%)$ & $15(9.9 \%)$ & $109(71.7 \%)$ & 1.717 & 1.319 \\
\hline Total Mean & & & & & & 1.445 & \\
\hline
\end{tabular}


The Table 5.8 proves that a total mean is 1.445 that shows strong tendency proving the relationship between skills contribution to sustainability of deaf donor funded project.

Table 5.11: Barriers to stakeholders' participation

\begin{tabular}{|c|c|c|c|c|c|c|c|}
\hline $\begin{array}{l}\text { Barriers to stakeholders } \\
\text { participation }\end{array}$ & 5 & 4 & 3 & 2 & 1 & Mean & Std. \\
\hline $\begin{array}{l}\text { Lack of information on project } \\
\text { design and planning }\end{array}$ & $0(.0 \%)$ & $6(3.9 \%)$ & $6(3.9 \%)$ & $16(10.5 \%)$ & $124(81.6 \%)$ & 1.302 & .7282 \\
\hline $\begin{array}{l}\text { Weak administration and } \\
\text { management }\end{array}$ & $0(.0 \%)$ & $0(0.0 \%)$ & $9(5.9 \%)$ & $25(16.4 \%)$ & $118(77.6 \%)$ & 1.282 & .5687 \\
\hline $\begin{array}{l}\text { Poor coordination of project } \\
\text { activities }\end{array}$ & $0(.0 \%)$ & $2(1.3 \%)$ & $6(3.9 \%)$ & $19(12.5 \%)$ & $125(82.2 \%)$ & 1.243 & .5867 \\
\hline Poor execution of project activities & $0(.0 \%)$ & $0(0.0 \%)$ & $11(7.2 \%)$ & $19(12.5 \%)$ & $122(80.3 \%)$ & 1.269 & .5865 \\
\hline $\begin{array}{l}\text { Failure to influence process of } \\
\text { project sustainability }\end{array}$ & $0(.0 \%)$ & $3(2.0 \%)$ & $6(3.9 \%)$ & $18(11.8 \%)$ & $125(82.2 \%)$ & 1.256 & .6250 \\
\hline $\begin{array}{l}\text { Poor legal framework of the } \\
\text { project }\end{array}$ & $0(.0 \%)$ & $0(.0 \%)$ & $15(9.9 \%)$ & $19(12.5 \%)$ & $118(77.6 \%)$ & 1.322 & 6469 \\
\hline Lack of expertise & $0(.0 \%)$ & $8(5.3 \%)$ & $2(1.3 \%)$ & $4(2.6 \%)$ & $138(90.8 \%)$ & 1.210 & .7153 \\
\hline $\begin{array}{l}\text { Lack of training and capacity } \\
\text { building }\end{array}$ & $0(.0 \%)$ & $6(3.9 \%)$ & $6(3.9 \%)$ & $16(10.5 \%)$ & $124(81.6 \%)$ & 1.302 & .7282 \\
\hline Limited resources & $0(.0 \%)$ & $0(0.0 \%)$ & $9(5.9 \%)$ & $26(17.1 \%)$ & $117(77.0 \%)$ & 1.289 & .5711 \\
\hline Apathy of stakeholders & $0(.0 \%)$ & $2(1.3 \%)$ & $6(3.9 \%)$ & $20(13.2 \%)$ & $124(81.6 \%)$ & 1.250 & .5896 \\
\hline $\begin{array}{l}\text { Lack of awareness on project } \\
\text { activities }\end{array}$ & $0(.0 \%)$ & $0(0.0 \%)$ & $11(7.2 \%)$ & $20(13.2 \%)$ & $121(79.6 \%)$ & 1.276 & .5890 \\
\hline Mistrust and poor accountability & $0(.0 \%)$ & $3(2.0 \%)$ & $6(3.9 \%)$ & $19(12.5 \%)$ & $124(81.6 \%)$ & 1.263 & .6275 \\
\hline Domination by elite & $0(.0 \%)$ & $0(0.0 \%)$ & $15(9.9 \%)$ & $20(13.2 \%)$ & $117(77.0 \%)$ & 1.328 & 6487 \\
\hline Illiteracy & $0(.0 \%)$ & $3(2.0 \%)$ & $6(3.9 \%)$ & $19(12.5 \%)$ & $124(81.6 \%)$ & 1.263 & .6275 \\
\hline Total Mean & & & & & & 1.275 & \\
\hline
\end{tabular}

Source: Primary Data (2020)

The findings in Table 5.9 proves that a total mean is 1.2758 which the above are stakeholders participation in promoting sustainability of deaf donor funded project.

Table 5.12: Correlation Analysis between stakeholder participation and sustainability of deaf donor funded project

\begin{tabular}{lllll}
\hline & & Ownership & Continuation & Effective Leadership \\
\hline \multirow{3}{*}{ Skills } & Pearson Correlation & $.851^{* *}$ & $.786^{* *}$ & $.837^{* *}$ \\
& Sig. (2-tailed) & .000 & .000 & .000 \\
\multirow{3}{*}{ Resources } & $\mathrm{N}$ & 152 & 152 & 152 \\
& Pearson Correlation & $.813^{* *}$ & $.513^{* *}$ & $.799^{* *}$ \\
& Sig. (2-tailed) & .000 & .000 & .000 \\
& $\mathrm{~N}$ & 152 & 152 & 152 \\
\multirow{3}{*}{ Material } & Pearson Correlation & $.911^{* *}$ & $.656^{* *}$ & $.899^{* *}$ \\
& Sig. (2-tailed) & .000 & .000 & .000 \\
& $\mathrm{~N}$ & 152 & 152 & 152 \\
& $\mathrm{~N}$ & 152 & 152 & 152 \\
\hline
\end{tabular}

Source: Primary Data (2020)

The findings in Table 5.12 proves that there is a relationship between skills and ownership $(\mathrm{p}=.851$ and sig=.000), between skills and continuation $(\mathrm{p}=.786$ and $\operatorname{sig}=.000)$, between skills and effective leader $(\mathrm{p}=.837 \mathrm{and}$ sig=.000), between resources and ownership $(\mathrm{p}=.813$ and sig=.000) between resources and continuation $(\mathrm{p}=.513$ and sig=.000) between resources and effective leader $(\mathrm{p}=.799$ and $\mathrm{sig}=.000)$ between material and ownership $(\mathrm{p}=.911$ and $\operatorname{sig}=.000)$ between material and continuation $(\mathrm{p}=.656$ and $\operatorname{sig}=.000)$ between material and effective leader $(\mathrm{p}=.899$ and sig=.000)because all calculated $\mathrm{p}$ - values are less than 0.01 level of significance. Thus, implies that there is a positive and significant relationship between participation of stakeholders and sustainability of Deaf donor funded project in Kicukiro District, Rwanda.

Table 5.13: Model summary of stakeholder participation and effective leadership as indicators of sustainability of deaf donor funded project

\begin{tabular}{lllll}
\hline Model & R & R Square & Adjusted R Square & Std. Error of the Estimate \\
\hline & $.916^{\mathrm{a}}$ & .838 & .835 & .21942 \\
\hline
\end{tabular}

a. Predictors: (Constant), Material, Skills, Resources

Source: Primary Data (2020) 
The Table 4.19 indicate that the R .916 coefficient suggests that stakeholder participation is related to the effective leadership of the project. The $.838 \mathrm{R}$ square coefficient of determination also suggests that stakeholder participation debts for $83.8 \%$ of increase variability in effective leadership of deaf donor funded project. Thus, implies that predictors of participation of stakeholders such as material, skills and resources that affect progress $83.8 \%$ of effective leadership of deaf donor funded project. These results are supported by the study of Pretty (2015) who asserted that stakeholder participation involve participation as a contribution to the implementation of a project with control over assets and decision making.

Table 5.14: Analysis of Variance (ANOVA) of stakeholder participation and effective leadership as an indicator of sustainability deaf donor funded project

\begin{tabular}{llllll}
\hline Model & Sum of Squares & Df & Mean Square & F & Sig. \\
\hline Regression & 36.954 & 3 & 12.318 & 255.851 & $.000^{\mathrm{b}}$ \\
Residual & 7.125 & 148 & .048 & & \\
Total & 44.079 & 151 & & & \\
\hline
\end{tabular}

a. Dependent Variable: Effective Leadership

b. Predictors: (Constant), Material, Skills, Resources

Source: Primary Data, 2020

The Table 5.14 show that there is a large relationship between stakeholder participation and effective leadership due to the fact the calculated p-value of 0.00 is less than 0.05 level of significance. Thus, the statistical model expecting correlation between participation of stakeholders and effective leadership of deaf donor funded project is significant.

Table 5.15: Coefficients of stakeholder participation and effective leadership as an indicator of sustainability of deaf donor funded project

\begin{tabular}{llllll}
\hline Model & Unstandardized B & $\begin{array}{l}\text { Coefficients } \\
\text { Std. Error }\end{array}$ & $\begin{array}{l}\text { Standardized } \\
\text { Beta }\end{array}$ & Coefficients T & Sig. \\
\hline (Constant) & -.007 & .049 & & -.134 & .893 \\
Skills & .315 & .065 & .298 & 4.813 & .000 \\
Resources & .031 & .090 & .031 & .341 & .033 \\
Material & .692 & .120 & .683 & 5.783 & .000 \\
\hline
\end{tabular}

a. Dependent Variable: Effective Leadership

Source: Primary Data, 2020

The results in Table 5.15 indicates that predictors of participation of stakeholders have positive coefficients that enhance positive effect on the progress of effective leadership in deaf donor funded project in Kicukiro District. The progress analysis proves that there is a positive significant between participation of stakeholders and effective leadership because all calculated p-values are lesser than 0.05 level of significance. Hence, the coefficients give regression model, $\mathrm{Y}=\beta 0+\beta 1 \mathrm{X} 1+\beta 2 \mathrm{X} 2+\beta 3 \mathrm{X} 3+\beta$. Therefore, it becomes $\mathrm{Y}=-.007+.315 \mathrm{X} 1-.031 \mathrm{X} 2+.692 \mathrm{X} 3$, this regression equations shows that there is a positive significant between participation of stakeholders and effective leadership of deaf donor funded project in Kicukiro District.

The first objective established to indicate the relationship between skills and effective leadership proves that there is a positive and significant relationship $(\mathrm{b}=.315$ and $\mathrm{p}=.000)$ which is lesser than 0.05 level of significance; the second objective established to indicate the relationship between resources and effective leadership has a positive and significant relationship $(b=.031$ and $p=.033)$ which is lesser than 0.05 level of significance; the third objective established to indicate the relationship between materials and effective leadership has a positive and significant relationship $(b=.692$ and $p=.000)$ which is lesser than 0.05 level of significance. Thus, implies that there is a positive significant relationship between participation of stakeholders and effective leadership of deaf donor funded project in Kicukiro District.

\section{Discussion}

This part of the study dealt with the discussion of findings, the results of the study have shown that local resources considered during the stakeholder participation has affected project sustainability as confirmed by 1.57499 of total mean. The results have also indicated that the total mean of 1.2669 shows a very great tendency to the perceptions asserting that donors influence local resources considered to promote project sustainability of donor-funded project in Kicukiro District. These results are supported by the studies of Ndegwa (2015) who asserted that stakeholder participation in the project involves material contribution and capacity either by direct or indirect beneficiaries. They added that resources through contribution of financial, personnel and human capital which make the project more sustainable.

The results have also indicated that an overall perception of 1.2758 total mean proves a strong tendency on the relationship between skills contribution to sustainability of deaf donor funded project. The results have also shown 
that material contribution plays a significant role to sustainability of deaf donor funded project by a total mean of 1.4230 which is supported by the study of Mukunga (2012) which revealed that the stakeholder interventions in the project has to include the sense of collaborative participation to enhance sustainability of the project. He also asserted that skills contribution showed an important contribution in sustainability at rate of $67.8 \%$ in the construction project.

The results revealed that the relationship between participation of stakeholders and sustainability of deaf donor funded project for instance the relationship between skills and ownership ( $\mathrm{p}=0.851$ and sig=.000), between skills and continuation $(\mathrm{p}=0.786$ and $\mathrm{sig}=.000)$. The findings are supported by means of Peter et al., (2013) who have proven that there is a relationship between the identification of one's very own needs and the sustainability of the firm with a Pearson correlation of 0.781 at 0.00 of calculated significance. The study also supported the results that show that participation with the assist of material donations or contribution is an integral issue for ownership at $32.1 \%$, therefore the sustainability of the intervention; gaining knowledge of also underscores the significance and usefulness if only people in the community had also been educated to take cost of the intervention in minor activities.

\section{Conclusion}

In conclusion, the previous studies that are related to stakeholder participation and project sustainability have demonstrated that project to be sustainable has factors such as the social, economic, and environmental, should be seen during project design and distribution of duties (Peter et al., 2013). This research concluded that there is an excellent relationship between the identification of one's own needs and the sustainability of the projectwith0.781 Pearson correlation and the calculated sig. value of 0.00 at 0.01 significance level. Stakeholder participation in the project entails the contribution of the material by both direct and indirect beneficiaries and plays an essential function in ensuring the sustainability of the project. Other research noted that stakeholder participation in projects helps increase resources, such as the financial, staffing, and manpower utilization that makes the project greater most economical and efficient in its operation (Mukunga, 2012 \& Ndegwa, 2015) .

Therefore, the current study demonstrated that perceived barriers to stakeholders' participation in promoting project sustainability demonstrated that the barriers are lack of lack of design on project design and planning, weak administration and management, poor coordination of project activities poor execution of project activities, failure to influence process of sustainability of deaf donor funded project, that poor legal framework of the project, lack of training and capacity building, limited resources is a challenge facing sustainability of deaf donor funded project strongly agree. There is a correlation between participation of stakeholders and sustainability of Deaf donor funded project in Kicukiro District for instance a positive relation is seen between skills and ownership $(\mathrm{p}=.851$ and $\mathrm{sig}=.000)$, between skills and continuation $(\mathrm{p}=.786$ and $\mathrm{sig}=.000)$, between material and effective leader $(\mathrm{p}=.899$ and $\mathrm{sig}=.000)$ since the $\mathrm{p}$-values calculated is less than 0.01 significance level.

\section{Acknowledgement}

I would like to thank the almighty God for the blessings and protection during compilation of this Research Project. My thanks and appreciations are extended to Dr. Safari Ernest and Dr. Osiemo A. Kengere who contributed a lot to my study as research supervisors, my classmates and my respondents for the kind participation in this study. Many appreciations go to my lovely husband, my daughter and son. I can never forget the effort made by my lecturers who thought me and the whole of Mount Kenya University staff for their academic supports provided to me while studying and conducting this research project.

\section{References}

[1].Bal, M., Bryde, D., Fearon, D. \& Ochieng, E. (2013). Stakeholders Engagement Achieving Sustainability in the construction sector. International Journal of project management, 11 (2), 15-20.

[2].Banerjee, A \& Chaudhury, S. (2010). Statistics without tears: Populations and samples. Industrial psychiatry journal, 19(1), 60-65. https://doi.org/10.4103/0972-6748.77642.

[3].Chizimba, M. (2013). The sustainability of donor funded projects in Malawi. Mediterranean Journal of Social Science, 11(4)705-1524.

[4].Cohen, J.M \&Uphoff, N.T. (2010).Participation's place in rural development: Seeking clarity through specificity. World Development Journal, 8 (3): 213-235.

[5].Mukunga, F. M. (2012). Influence of community participation on the performance of water projects.

[6].Unpublished Master Thesis. University of Nairobi. Kenya.

[7].Ndegwa, A. (2015). Factors influencing the sustainability of KEMRI HIV / AIDS Grants funded projects in Kenya, the University of United Sate International Africa.

[8].Peter, G., George, T., Kirui, K. \&Luvega, C. (2013). The Dilemma in sustainability of Community Based Approach. Global journal of advanced research, 21 (3), 134-144.

[9].Pretty, J. (2015).Participatory Learning for Sustainable Agriculture. World Development, New York. USA. Till, R. E., \&Yount, M. B. (2018). Governance and incentives: Is it really all about the money? Journal of Business Ethics, 159(3), 1-14. doi:10.1007/s10551-018-3778-5

[10]. Yamane, T. (1967).Statistics: An Introductory Analysis, $2^{\text {nd }}$ Edition, New York: Harper and Row 